\title{
IMPLEMENTASI CLUSTER SERVER BERBASIS LINUX SEBAGAI LEARNING MANAGEMENT SYSTEM (LMS) DI SMK MUHAMMADIYAH 2 PEKANBARU
}

\author{
Yoyon Efendi ${ }^{1}$, Hendra Lismanda ${ }^{2}$, Dwi Haryono ${ }^{3}$ \\ Teknologi Informasi, STMIK Amik Riau ${ }^{1,2}$,Manajemen Informatika, STMIK Amik Riau ${ }^{3}$ \\ yoyonefendi@stmik-amik-riau.ac.id ${ }^{1}$, hendralismanda@stmik-amik-riau.ac.id ${ }^{2}$, dwiharyono@ stmik- $^{2}$ \\ amik-riau.ac.id ${ }^{3}$ \\ DOI: http://dx.doi.org/10.31869/rtj.v2i2.1264
}

\begin{abstract}
Learning systems need help to support progress in the field of education. Problems that exist in Muhammadiyah 2 Pekanbaru Vocational School have not yet implemented a Learning Management System (LMS) system that has an impact on students and teachers, compilation teachers cannot discuss learning jams certainly greatly affect students, teachers who are unable to attend specifically at teaching hours. Learning methods by implementing Learning Management Systems that will run on the Ubuntu Server 16.04 LTS Linux operating system. The system contains features such as Moodle, Big BlueButton, and Video Confrence needed in the teaching and learning process. By using the Learning Management System the teacher can manage classes and exchange information with students. Using labor can use learning and video conferencing management systems to keep discussing and providing learning material to students when attending is present at the time of learning using the internet.
\end{abstract}

Keywords: LMS, Server Cluster, Moodle, Big bluebutton, Muhammadiyah 2 Vocational School Pekanbaru

Abstrak: Sistem pembelajaran membutuhkan suatu inovasi guna untuk mendukung kemajuan dibidang pendidikan. Masalah yang terdapat pada SMK Muhammadiyah 2 Pekanbaru belum diterapkan sistem Learning Management System (LMS) hal tersebut berdampak pada siswa dan guru, ketika guru tidak bisa menghadiri jam pembelajran tentu sangat berdampak pada siswa, terutama guru yang berhalangan hadir pada jam mengajar. Metode pembelajaran dengan menerapkan Learning Management System yang akan berjalan pada sistem operasi Linux Ubuntu Server 16.04 LTS. Sistem berisi fitur-fitur antara lain seperti Moodle, Big BlueButton, dan Video Confrence yang dibutuhkan dalam proses belajar mengajar. Dengan menggunakan Learning Management System guru dapat mengelola kelas dan bertukar informasi dengan siswa. Sehingga tenaga kerja dapat menggunakan learning management system dan video confrence untuk tetap mengawasi dan memberi materi pembelajaran kepada siswa/siswi pada saat berhalanagan hadir diwaktu pembelajaran dengan memanfaatkan internet.

Kata kunci: LMS,Cluster server, Moodle, Big bluebutton, SMK Muhammadiyah 2 Pekanbaru

\section{PENDAHULUAN}

Learning Management System (LMS) adalah suatu aplikasi perangkat lunak (software) untuk keperluan kegiatan proses belajar mengajar dan kegiatan secara online (terhubung ke internet) atau dalam bahasa lain disebut E-learning. Sistem pembelajaran membutuhkan suatu inovasi guna untuk mendukung kemajuan dibidang pendidikan, masalah yang terdapat pada SMK Muhamadiyah 2 Pekanbaru belum diterapkanya sistem E-learning, hal tersebut berdampak pada siswa dan guru, ketika guru tidak bisa menghadiri jam pembelajaran tentu sangat berdampak pada siswa, terutama guru yang berhalangan hadir pada jam megajar yang disebakan oleh beberapa faktor seperti sakit, pelatihan, rapat dan beberapa sebab yang tidak memungkin untuk hadir pada jam mengajar. Keterbatasan waktu belajar mengajar didalam kelas adalah sesuatu hal yang harus diperhatikan, karena materi yang didapatkan oleh siswa sangatlah minim. Hal ini tentu sangat berpengaruh pada sistem pembelajaran baik terhadap guru maupun siswa sekolah.

Dengan memanfaatkan Implementasi Cluster Server Berbasis Linux Sebagai Media Learning Management System, dapat mengurangi masalah pada SMK Muhamadiyah 2 tentunya mempermudah guru dan siswa 
dalam melakukan pembelajaran dengan menggunakan Learning Management System. System pembelajaran yang akan dibuat dalam bentuk video conference dengan memanfaatkan BigBlueButton sebagai wadahnya, dan video conference ini bisa dimanfaatkan untuk menunjang media conference guru berguna untuk meningkatkan kinerja guru dan fasilitas Pendidikan pada SMK Muhammadiyah 2. Sedangkan Cluster Server digunakan sebagai pengelompokan suatu server yang dapat saling bekerjasama dalam pemerosesan suatu masalah dan dapat menghasilkan kecepatan yang sangat tinggi pada kinerja server.

Untuk mengatasi masalah tersebut dibutuhkan sebuah sistem LMS (Learning management system). Learning management system merupakan salah satu inovasi yang berguna sebagai sarana untuk mendukung pembelajaran, proses belajar mengajar dan berguna untuk media conference guru. Learning management system yang akan diterapkan pada SMK Muahammadiyah 2 untuk memudahkan guru dalam proses belajar mengajar, tentu juga mempermudah siswa dalam mendapatkan materi pembelajaran.

Cluster Server

Menurut (Ade Jamal, 2006) defenisi cluster dalam dunia Teknologi Informasi dapat memiliki beberapa pengertian. Secara umum definisi Cluster adalah sejumlah komputer (PC ataupun workstation) yang digabungkan sebagai satu kesatuan dengan bantuan piranti lunak dan jaringan computer.

Menurut (Ramadhani, n.d.) Cluster server adalah istilah dari penyatuan sekelompok data yang mempunyai korelasi atau karakteristik sejenis, berarti kita menyatukan PC-PC atau server (atau apapun device yang ber-OS) ke dalam satu kesatuan komputasi.

\section{Learning Management System}

Learning Management System (LMS) adalah suatu aplikasi perangkat lunak (software) untuk keperluan kegiatan proses belajar mengajar dan kegiatan secara online (terhubung ke internet), misalnya administrasi, dokumentasi, pembuatan laporan dari sebuah kegiatan proses belajar mengajar, materi yang diajarkan disediakan secara online berbasis web dan dapat diakses melalui internet. Intinya LMS merupakan aplikasi yang mengotomasi dan mem-virtualisasi proses belajar mengajar secara elektronik. Learning Management System (LMS) merupakan sebuah paket solusi yang dirancang untuk penyampaian, pelacakan, pelaporan dan pengelolaan materi belajar, serta memantau kemajuan dan interaksi dari peserta didik.

LMS juga menyediakan fitur-fitur yang dapat memenuhi semua kebutuhan dari pengguna dalam hal proses pembelajaran. Saat ini ada banyak jenis LMS yang ditawarkan, setiap jenis LMS memiliki fitur-fiturnya masing-masing sesuai dengan fasilitas yang telah diberikan. LMS dapat berisi materi-materi yang dikemasan dalam bentuk multimedia (teks, animasi, video, sound), yang diberikan sebagai supplement danenrichment bagi pengembangan kompetensi pembelajar. LMS menawarkan sistem pembelajaran inovasi yang mencakup dalam bidang teknologi informasi, khususnya yang berbasis virtual melalui web online learning, multimedia dan Video Conference. LMS pembelajaran berbasis web dikembangkan secara dinamis (dinamic $E$ Learning). (W, 2013)

\section{Moodle}

Moodle merupakan jalan menuju pendidikan tanpa batas dan merupakan aplikasi yang dapat mengubah sebuah media pembelajaran ke dalam bentuk web. Moodle juga merupakan sebuah course management system yang digunakan untuk membuat sebuah proses belajar (learning) bisa dilakukan secara online, powerful dan fleksibel.

Moodle (Modular Object Oriented Dynamic Learning Environment) merupakan rancangan software untuk kegiatan pembelajaran berbasis internet dan website yang dapat digunakan secara bebas sebagai produk open source. (Sampurno, Maulidiyah, \& Puspitaningrum, 2015).

\section{BigBlueButton}

Menurut (Ismail, Mulyana, \& Tulloh, 2016) BigBlueButton adalah software open source yang berfungsi sebagai webRTC (web realtime communication) yang bisa digunakan sebagai server web conference, dimana semua berbasis web dan berkomunikasi web.

Dimana di dalam software BigBlueButton terdapat komponen-komponen yang mendukung dalam software ini seperti untuk, me-uploadfile presentasi, audio streaming, video streaming.

$\begin{array}{lr}\text { Fakultas Teknik UMSB } & \text { ISSN 2599-2081 } \\ \text { EISSN 2599-2090 }\end{array}$




\section{Video Conference}

Menurut (Ismail et al., 2016) Video Conference memiliki artian adalam setiap kata yaitu, Video $=$ video, serta Conference $=$ konferensi. Maka Video Conference adalah konferensi video dimana data yang ditransmisikan dalam bentuk video serta audio. Komunikasi dalam Video Conference menggunakan audio serta video yang bisa dilakukan dalam berbeda-beda tempat, bisa berupa dua lokasi (point-to-point) atau mengikutsertakan beberapa lokasi yang berbeda (multi-point). Teknologi utama yang dilakukan dalam Video Conference adalah kompresi digital dari suara serta video stream yang real time. Dengan adanya sistem kompresi digital ini memudahkan audio serta video dikirimkan dalam satu jaringan dengan menggunakan bandwidth yang seefisien mungkin dan memiliki kualitas yang dapat diterima. Adapun jenis-jenis Video Conference berdasarkan hubungan diantara pemakainya adalah sebagai berikut:

a. Real Time Colaboration Multiparty Conferencing, merupakan sarana hubungan konferensi seketika dengan resolusi yang baik dan interaktif.

b. Active Participation Users, merupakan hubungan yang terjadi antara pemakai dengan jaringan komputer atau basis data, konferensi yang seketika dengan resolusi yang baik dan interaktif.

c. Passive Participation User, merupakan keikutsertaan peserta yang pasif dan memerlukan hubungan yang seketika.

\section{METODE PENELITIAN}

Metode penelitian pada implementasi Cluster server berbasis linux sebagai Learning Management System (LMS) di SMK Muhammadiyah 2 Pekanbaru melalui proses analisa sistem untuk mengidentifikasi permasalahan-permasalahan yang ada pada sistem yang meliputi perangkat keras (hardware), perangkat lunak (software) serta analisa kebutuhan sistem dan elemen-elemen yang terkait pada penelitian.

Setelah analisis dari kebutuhan-kebutuhan fungsional, dan menggambarkan bagaimana sebuah sistem itu dibentuk termasuk mengkonfigurasi dari komponen perangkat keras dari sebuah sistem. Untuk menjelaskan proses secara detail dari pembutan Learning
Management System dan Video Conference tersebut diperlukannya alur kerja yang dapat memudahkan tahapan saat implementasi dilakukan sehingga tahapan dari sistem perancangan lebih terarah dan sesuai dengan tujuan.

\section{Tahapan Instalasi Software dan package}

Pada tahap ini, mengumpulkan software dan package yang diperlukan, untuk dilakukan penginstallan pada sistem yang akan dijalankan sebagai berikut:

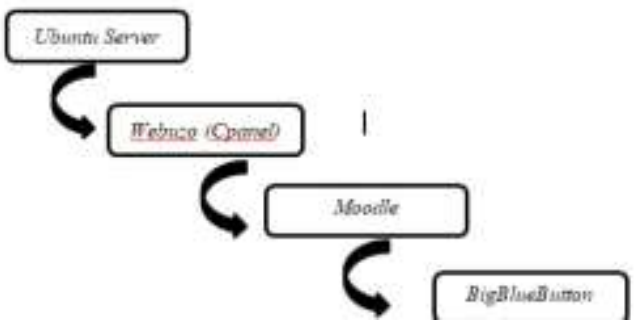

Gambar 1 Tahap Instalasi Software atau Package.

\section{Konfigurasi Server}

Tahap berikutnya konfigurasi server dengan gambaran berikut:

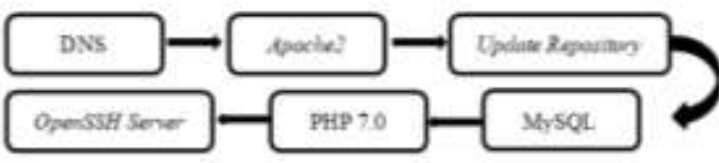

Gambar 2 Konfigurasi Server.

\section{Arsitektur Learning Management System (LMS)}

Arsitektur Learning Management System $(L M S)$ ini bisa diakses setiap saat, dan memungkinkan siswa tidak akan ketinggalan informasi setiap materi yang diberikan oleh guru. Diantara aktifitas yang dapat di lakukan pada Learning Management System (LMS) adalah:

\section{Assignment}

Dengan aktifitas ini guru dapat memberikan tugas yang mengharuskan siswa untuk mengirim file, dengan beberapa jenis tugas seperti tugas project, laporan, dan lain-lain.

2. Quiz

Aktifitas ini sangatlah sederhana, guru memberikan beberapa pertanyaan dan menyediakan beberapa pilihan pada jawaban, yang berisi multiple choice seperti true or flase, dan $\mathrm{ABCD}$. 


\section{Choice}

Aktifitas ini dapat memberikan pertanyaan dalam bentuk soal-soal pilihan ganda dan sebagainya. Siswa mengerjakan soal tersebut dan feedback nilai dapat dilihat secara langsung

4. Chat

Dengan aktifitas ini, setiap siswa dapat berdiskusi secara real-time via web, bukan hanya siswa dan siswa tetapi siswa dan guru tetap dapat ber interaksi secara langsung.

\section{Live streaming}

Pada aktifitas ini siswa dapat berinteraksi secara langsung dengan guru maupun dengan siswa lain, dengan memanfaatkan fitur chat dan video yang ada dalam aktifitas ini. Guru dalam aktifitas ini dapat mengupload file yang berguna untuk melakukan persentasi secara langsung dengan siswa.

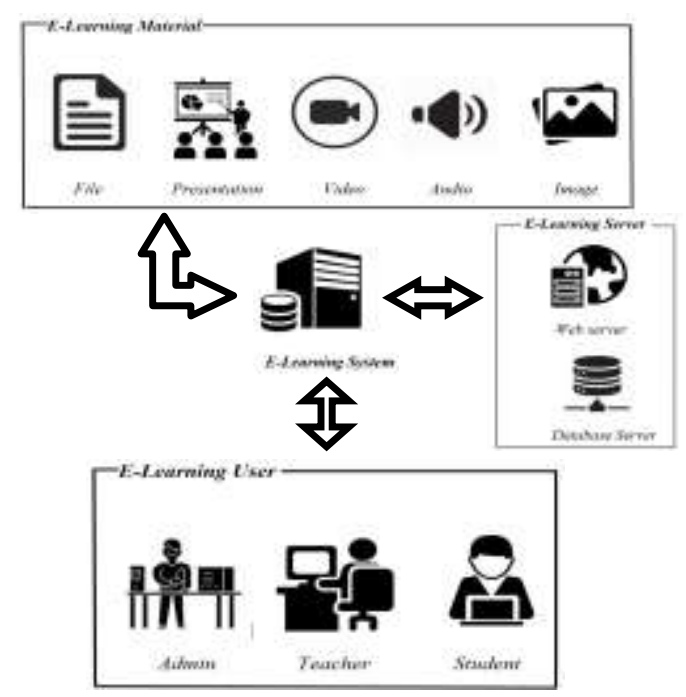

Gambar 3 Arsitektur LMS

HASIL DAN PEMBAHASAN

Implementasi Software dan Package

Dalam implementasi sistem ini dibutuhkan beberapa tahapan yang akan dijalankan seperti instalasi software dan package dan konfigurasi server, untuk mendukung dalam pembuatan sistem ini

\section{Ubuntu Server}

Setelah instalasi selesai, masuklah kedalam ubuntu server untuk login kedalam server, dengan memasukan username dan passwords seperti gambar dibawah ini:

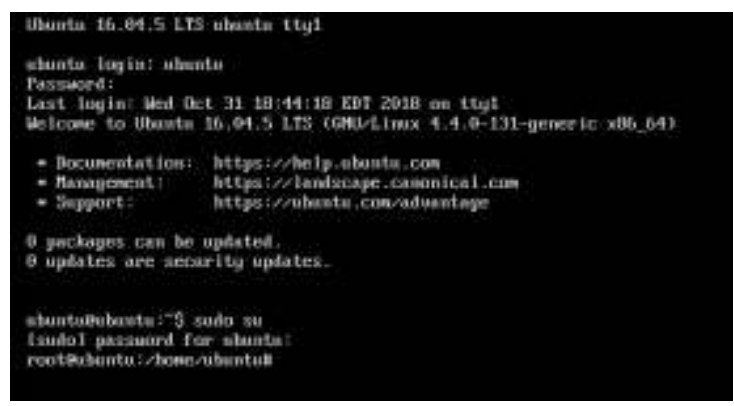

Gambar 4 Tampilan ubuntu server.

\section{Cpanel Webuzo}

Setelah melakukan instalasi Cpanel webuzo selesai seperti gambar dibawah ini:

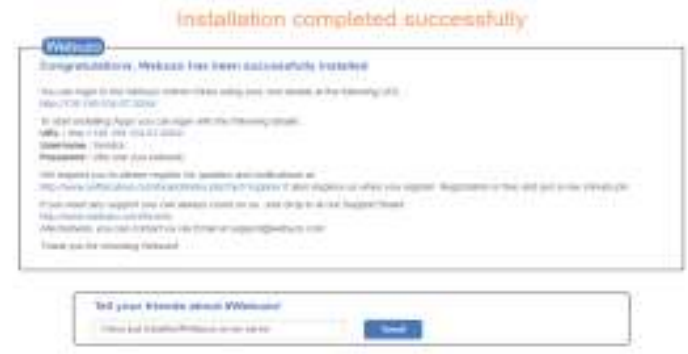

Gambar 5 Tampilan webuzo selesai.

\section{Moodle}

instalasi moodle, tahap ini telah menentukan bahwa instalasi moodle telah selesai seperti gambar diba

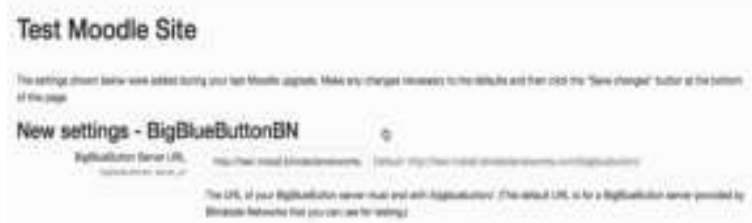

Gambar 6 Tampilan moodle

\section{BigBlueButton}

Setelah instalasi BigBlueButton, dan lakukan settingan default, dapat dilihat pada gambar berikut: 


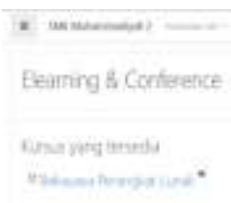

Gambar 7 Tampilan BigBlueButton

\section{Hasil Implementasi}

Hasil implementasi LMS dapat berjalan dan dapat memenuhi kebuthan user SMK Muhammadiyah 2 Pekanbaru. Adapun pembahasan hasil pengujian terdiri dari :

a. Guru

Setelah guru berhasil login kedalam sistem maka akan tampil menu utama, dan bagian setting pada guru hanya bisa membuat kursus terhadap siswa seperti gambar dibawah ini:

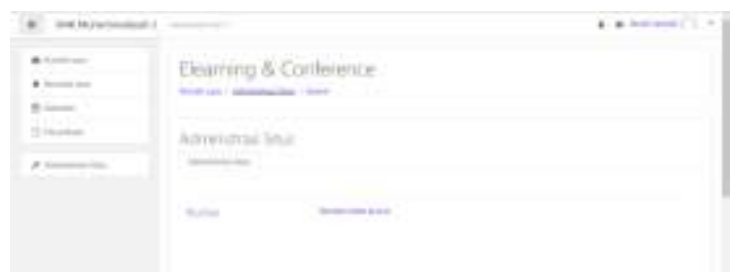

Gambar 8 Tampilan menu guru.

Untuk pembuatan kursus Live streaming guru harus login kedalam sistem. Dapat dilihat pada gambar dibawah ini:

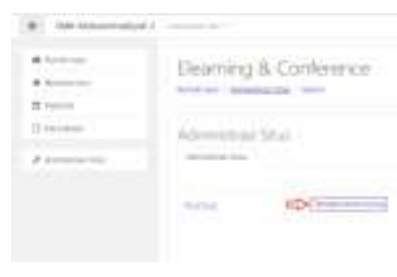

Gambar 9 Tampilan pembuatan kursus.

Setelah aktifitas BigBlueButton dibuat akan muncul tampilan aktifitas seperti gambar dibawah ini:

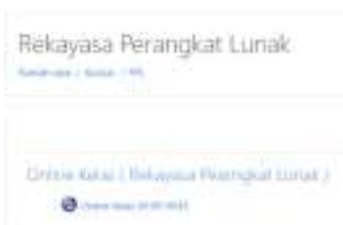

Gambar 10 Tampilan aktifitas kursus.
Setelah loading selesai, kita akan mendapatkan 2 pilihan pada audio seperti gambar dibawah ini.

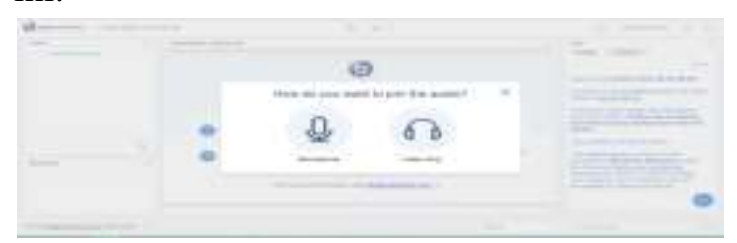

Gambar 11 Tampilan pemilihan audio. Secara otomatis kamera pada laptop atau komputer akan aktif, dan klik Start Sharing kamera agar user atau guru bisa melihat aktifitas yang dilakukan seperti gambar dibawah ini:

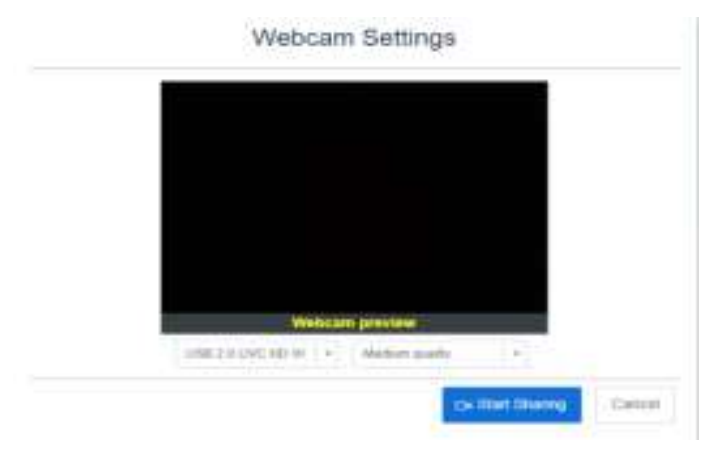

Gambar 12 Tampilan Webcam preview. Setelah itu untuk mengupload file prsentation seperti gambar dibawah ini:

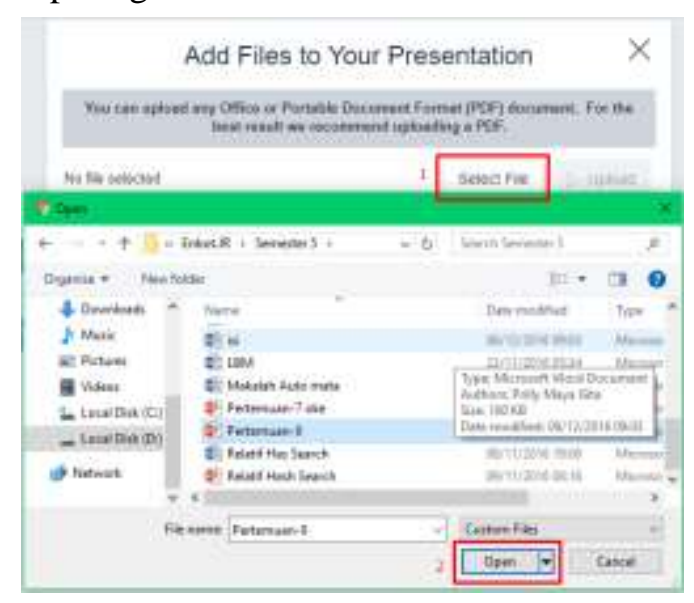

Gambar 12 Tampilan pemilihan file persentation

Setelah itu, maka pembelajaran secara live streaming sudah bisa dijalankan. Dapat dilihat pada gambar dibawah ini: 


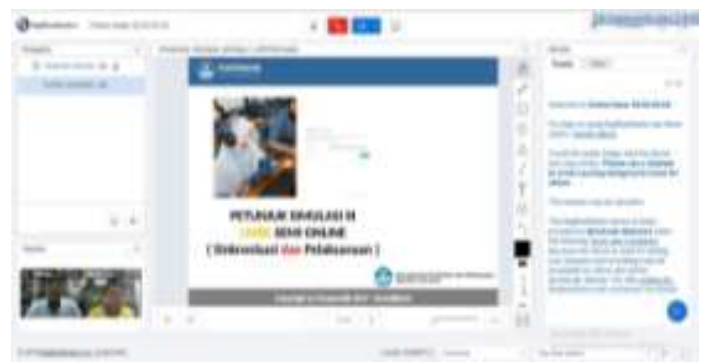

Gambar 12 Tampilan pembelajaran live streaming bagi guru.

b. Siswa

Setelah User/Student berhasil login kedalam sistem maka akan tampil menu utama dari sistem seperti gambar dibawah ini:

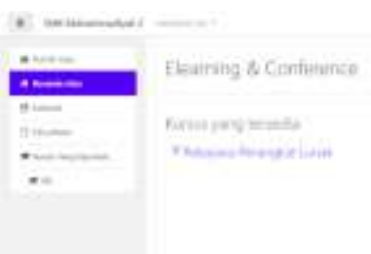

Gambar 13 Tampilan awal Student.

lalu Student melakukan live streaaming seperti gambar berikut:

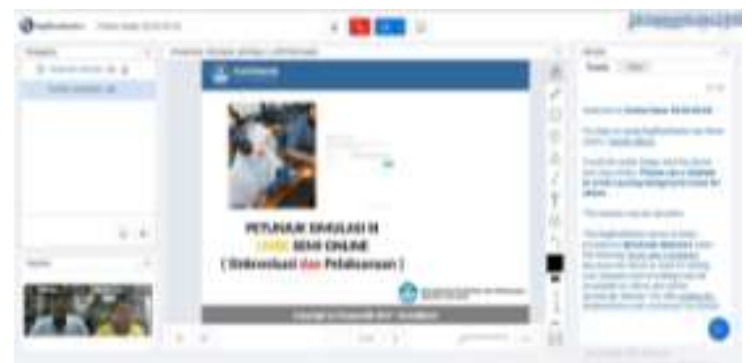

Gambar 14 Tampilan pembelajaran live streaming bagi siswa.

\section{PENUTUP}

Kesimpulan berisi rangkuman singkat atas hasil penelitian dan pembahasan adalah:

1. Dengan menggunakan Learning Management System guru dapat mengelola kelas dan bertukar informasi dengan siswa dan kelas tetap bisa berjalan dengan baik.

2. Sistem ini diharapkan bisa berajalan dengan baik dan bisa mengatasi masalah yang pada SMK Muhammadiyah 2 Pekanbaru terutama pada jurusan Teknologi Komputer dan Jaringan.

\section{UCAPAN TERIMAKASIH}

Terima kasih kepada STMIK Amik Riau, SMK Muhammadiyah 2 Pekanbaru dan semua pihak yang telah membantu pada penelitian ini.

\section{DAFTAR PUSTAKA}

Ade jamal, P. S (2006). Kinerja Komunikasi Data Kolektif Broadcast pada pc cluster, 2006, 435-444.

Hariyadi, S., and M. Kom. "Sistem Komunikasi Fiber Optik Dan Pemanfaatannya Pada PT. Semen Padang." Rang Teknik Journal 1.1 (2018).

Ismail, M.,Mulyana, A., \& Tulloh, R. (2016). Perancangan dan realisasi sistem perkuliahan jarak jauh dengan mode teleconference berbasis multimedia (server video confernce) design,2(3), 1304-1310.

P.R.E., kom, S., Rachman, A., \& H.T.W. (2016). Virtual private server (VPS) sebagai alternatif pengganti dedicated server. Sitia, 2-7.

Pane, D.K.(2013). Implementasi data mining pada penjualan produk elektronik dengan algoritma apriori (studi kasus : kreditplus). Pelita informatika budi darma valume : I,2529,https://doi.org/2301-9425

Ramadhani , H. (n.d). diskkless system standar dengan diskless system.

Ronald budi. (2013). Administrasi server dalam jaringan menggunakan linux. PT Skripta Media Creative

Sampurno.P.J., Maulidiyah, R., \& Puspitaningrum, H. Z. (2015). Implementasi Kurikulum 2013: MOODLE (Modular Objeck Oriented Dynamix Learning Environment) dalam pembelajaran fisika melalui lembar kerja siswa pada meteri optik di SMA. Jurnal fisika indonesia, XIX(55), 54-58.

Satria, F.D., Ariefianto, T., \& Yovita, L. V. (2014). Implementasi dan analisis server clustering menggunakan cluster file system pada san (Storage Area Network) berbasis 1sesi untuk layanan cloud storage

W, L. A. S. (2013). Perancangan E-Learning dengan menggunakan Learning Manangement system (LMS). Widya Warta, 35(02), 332-341. 